\title{
TOMASINI BASSOLS, ALEJANDRO, PECADOS CAPITALES Y FILOSOFÍA, MÉXICO: PLAZA Y VALDÉS, 2012, 268 PP.
}

\section{PAMELA LASTRES}

Pontificia Universidad Católica del Perú

Aparecido en setiembre de 2012, Pecados capitales y filosofía presenta un fecundo estudio filosófico sobre los siete pecados capitales del cristianismo tradicional proyectados a los vicios o defectos ordinarios de la vida contemporánea, vale decir, a aquellos males comunes que diariamente nos infligimos unos a otros. Su autor, el reconocido filósofo mexicano Alejandro Tomasini Bassols, realiza un examen lúcido, cuidadoso y original de pecados y pecadores. Dicho análisis lo conduce a discutir cuestiones que caen principalmente en los campos de la filosofía de la religión, de la ética y de la antropología filosófica.

¿Qué tipo de libro es este y qué trae de nuevo? Una rápida revisión de la bibliografía reciente en castellano muestra que existe al menos un ensayo anterior de Fernando Savater dedicado al mismo tema ${ }^{358}$. Sin embargo, como podría esperarse de cualquier texto de divulgación, el libro de Savater está básicamente compuesto por digresiones, anécdotas y citas más o menos amenas articuladas alrededor de los siete pecados capitales.

El libro de Tomasini Bassols, a diferencia del ensayo de Savater, produce el efecto de una conversación inteligente con un competente y riguroso filósofo. Este estudio hace mucho más que entretener e impartir información. Desde sus primeras páginas, exhibe una prosa filosófica de raigambre analítica: se inicia con consideraciones sobre el lenguaje, el significado y la semántica.

358 Cf. Savater, Fernando, Los siete pecados capitales, Barcelona: Debate, 2005. 
Tomasini Bassols emplea el método wittgensteiniano de análisis conceptual o gramatical orientado a iluminar el concepto de pecado capital y a analizar sus múltiples expresiones históricas en la vida humana. Basado en la consideración de casos concretos, este método se lleva a la práctica mediante diversas actividades intelectuales. Algunas de ellas son, por ejemplo, hacer explícitas las imágenes arraigadas en nuestra manera de describir ciertos eventos, concebir juegos de lenguaje como objeto de comparación, identificar falsas analogías o mostrar la poca pertinencia de determinados planteamientos teóricos. Posee este método interesantes características: es básicamente elucidatorio -tiene como principal cometido arrojar claridad sobre el problema estudiado-, es prima facie descriptivo -no persigue explicaciones generales sino descripciones esclarecedoras-, no violenta las reglas de uso, obliga constantemente a proporcionar ejemplos, invita a considerar distinciones, y se encuentra anclado en las formas humanas de vida, vale decir, en aquellas prácticas sociales que dibujan el paisaje de nuestra vida cotidiana.

Encuentro que este estudio es también testimonio de un esfuerzo por recuperar el sentido y el valor del lenguaje religioso. Se requiere, en efecto, el lenguaje religioso para rastrear y describir nuestras formas de vida, así como para identificar y examinar las fallas que forman parte del complejo cuadro general de las conductas del ser humano. Pero siempre será preciso desbrozar, contextualizar y actualizar esas expresiones. Si bien hoy podemos usar y comprender el significado de términos como "pecado", "infierno" y "salvación", no los experimentamos de la misma manera en que lo hicieron, por ejemplo, los monjes benedictinos de siglo VI, Santo Tomás de Aquino o el Tribunal del Santo Oficio de la Inquisición. Las consideraciones de Tomasini Bassols sobre la obsolescencia y las limitaciones de esta terminología parecen orientadas, de paso, a minar cualquier aproximación metafísica o naturalista a la condición humana que pretenda concebirla como algo rígido e inmutable.

El término "pecado" supone perpetrar una ofensa contra Dios; los pecados son, en este sentido, intentos humanos por subvertir un orden divino. La expresión "capital" está vinculada a vocablos latinos que refieren a la cabeza. A diferencia del controvertido pecado original-noción problemática desde perspectivas filosóficas y teológicas-, diríamos que estos pecados son capitales no solo por su gravedad, sino sobre todo por su facilidad para incitar la 
comisión de otros pecados: están a la cabeza, pues de ellos se desprende un alud de vicios menores.

Nuestro autor explora el origen histórico del concepto de "pecado capital"; señala, asimismo, que la razón principal para incluir estos siete elementos en la lista obedeció principalmente a necesidades prácticas de la Iglesia católica: acuciada por expandir su influencia, la institución asimiló a numerosas personas. No es difícil imaginar hasta qué punto estos vicios tan frecuentes resultaron particularmente nocivos a efectos de mantener el orden interno y de salvaguardar la honorabilidad de la Iglesia Católica ${ }^{359}$. Posteriormente, ante las dificultades de atender a las peculiaridades conductuales de comunidades y personas, la lista atribuida a Gregorio el Grande extendió su ámbito de injerencia y acabó generalizándose. La noción de pecado capital podría encontrar también vasos comunicantes con conceptos jurídicos contemporáneos como el de código penal, pero no es esta la pista que sigue este libro.

Además de contar con una presentación y con una sección de cierre dedicada a exponer reflexiones finales, el libro estudia por separado estos siete condenables modos de ser: la soberbia, la envidia, la pereza, la avaricia, la ira, la gula y la lujuria. Tomasini Bassols lleva a cabo con acierto y perspicacia el ejercicio filosófico de esclarecer y colocar en su lugar a estos vicios, aunque no presta demasiada atención a su dimensión política. Estimo, por ello, que resultaría provechoso leer este libro conjuntamente con Vicios ordinarios, el célebre ensayo de la politóloga Judith Shklar ${ }^{360}$.

La soberbia -acaso el peor de los pecados capitales- se encuentra vinculada, como lo sugiere Tomasini Bassols, con el orgullo desmedido, la vanagloria y la arrogancia; mas también, como lo muestra Shklar, posee una faceta política: el esnobismo ${ }^{361}$. El capítulo dedicado a la envidia invita al lector a distinguirla de los celos y a notar su compleja especificidad que la distancia de cuestiones más políticas como la del resentimiento social. Una de las secciones más interesantes es la dedicada a la pereza: por un lado, Tomasini Bassols muestra

359 Los monjes a menudo lamentaban el que después del almuerzo del mediodía (post meridiem) fueran asaltados por demonios meridianos, lo que indica cierta inevitable propensión a la pereza, la acedia y la lujuria.

360 Cf. Shklar, Judith, Vicios ordinarios, México D.F.: Fondo de Cultura Económica, 1990.

36I El análisis de Shklar muestra cómo esnobismo y racismo pertenecen a la misma familia. 
que el uso que hacemos hoy del término "pereza" se aleja considerablemente del que tuvieron en mente los padres de la Iglesia; por otro lado, ofrece muy sugerentes reflexiones sobre la acedia, una forma particular de pereza de carácter mental y espiritual.

En el análisis de la avaricia, Tomasini Bassols se ciñe al enfoque tomista y esboza una crítica a Aristóteles: sostiene que el tratamiento aristotélico de la avaricia no toma en cuenta la perspectiva de la primera persona. Aquí habría que precisar que a Aristóteles le interesa el impacto político que posee un vicio como la pleonexia: esta es descrita por el estagirita como codicia o, más propiamente, como el deseo de poseer más de lo que a uno le corresponde. Consecuentemente, la pleonexia tendría menos relevancia como vicio privado que como fuente de injusticias.

El capítulo dedicado a la ira la presenta como un obstáculo para la acción equilibrada. Explora las delicadas diferencias entre ira y cólera, pero también su conexión con la violencia. No puedo dejar de subrayar el interés y la vigencia que tiene el análisis de la gula: uno de los discursos más poderosos sobre la comida que circulan actualmente es el de la gastronomía, que se ha expandido enormemente, hasta el punto de que proliferan revistas y publicaciones especializadas dedicadas enteramente a él. Tomasini Bassols destaca los nexos con el sibaritismo y el hedonismo. En términos aristotélicos, la gula es un vicio por exceso. Un examen kantiano mostraría igualmente su carácter moralmente inaceptable, mientras que un análisis de corte utilitarista arrojaría que la gula no es moralmente reprochable. Finalmente, el tratamiento de la lujuria se inicia con consideraciones históricas e incluye un análisis sobre el deseo sexual.

Los interesados en la discusión de problemas éticos encontrarán que el autor de este estudio proporciona las claves fundamentales para comprender los pecados capitales y los sutiles modos en que ellos resuenan en las formas de vida contemporáneas. No me queda sino recomendar a los lectores que se sumerjan en el acto en estas páginas, que son ejemplo de la mejor expresión del ejercicio filosófico. 